\title{
Comparative Study Between Theoretical and Experimental Values of Dimensional Quantities for Tropical Brazilian Wood
}

\author{
Tiago Hendrigo de Almeida ${ }^{1}$, Fabiane Salles Ferro ${ }^{2}$,
} Diego Henrique de Almeida ${ }^{3}$, André Luis Christoforo ${ }^{4}$, Francisco Antonio Rocco Lahr ${ }^{5}$

\author{
${ }^{1}$ Department of Science and Materials Engineering, University of São Paulo (EESC/USP), São Carlos, São Paulo, SP, \\ Brasil. \\ ${ }^{2}$ Department of Forest Engineering, Midwestern State University (UNICENTRO), Irati, Paraná, PR, Brasil. \\ ${ }^{3}$ Department of Civil Engineering, Federal University of Rondônia (UNIR), Porto Velho, Rondônia, RO, Brasil. \\ ${ }^{4}$ Department of Civil Engineering, Federal University of São Carlos (UFSCar), São Carlos, São Paulo, SP, Brasil. \\ ${ }^{5}$ Department of Structural Engineering, University of São Paulo (EESC/USP), São Carlos, São Paulo, SP, Brasil. \\ e-mail: tiago.hendrigo@gmail.com, fabi.salles.ferro@gmail.com, diegoestruturas@gmail.com, christoforoal@yahoo. \\ com.br, frocco@sc.usp.br
}

\begin{abstract}
Brazil presents many wood species that are very useful in several sectors such as civil construction and furniture industry. Rational use of wood resources depends on the wood characterizations process, that can become easier using equations involving properties of interest. Some theoretical equations found in the literature were developed for primarily softwood from the northern hemisphere, but not checked regarding of their accuracy for tropical Brazilian wood species. This paper aims to confront four theoretical equations with the dimensional stability quantities of fifteen tropical Brazilian woods and test the accuracy of them for these wood species. Results showed that experimental values present greater variability than the ones provided by the theoretical equations. Kruskal-Wallis ANOVA performed showed that one of the four equations cannot be accurately used for tropical Brazilian wood species at 5\% significance level.
\end{abstract}

Keywords: Accuracy. Material. Physical properties. Wood.

\section{INTRODUCTION}

Civil construction, furniture industry and paper and pulp industry are sectors where wood is used as raw material [1-4]. Steege et al. [5] point that there are about 12 thousand tropical wood species in Brazil without any characterization. For good utilization of wood resources, it is necessary to characterize its physical, chemical and mechanical properties [6-9]. The Brazilian standard code ABNT NBR 7190/1997 "Design of Timber Structures" [10] prescribes the procedures for structural design based on eight strength classes determined by the characteristic value of the strength in compression parallel to grain [6]. All physical and mechanical properties of wood that are important for structure design might be determined according to the Annex B "Determination of wood properties for structural design" of the Brazilian standard code. The five strength classes for hardwoods preconized by the ABNT NBR 7190/1997 are used also by researchers for better compose the sampling activity [11-13], leading these works to more generalized conclusions.

A very useful literature for wood researchers and wood properties learners is the book "Principles of Wood Science and Technology" by Kolmann and Côté [14]. This title brings many information about chemical physical and mechanical properties of wood. About physical properties, swelling and shrinkage of wood, as well as wood densities, are very discussed based on information from these authors and other contemporary authors of them.

Kolmann and Côté [14] presents some equations related to quantities of wood dimensional stability involving shrinkage and swelling coefficients (volumetric, tangential and radial directions), density at $0 \%$ moisture content, fiber saturation point and basic density. These concepts have been developed primarily based on softwoods from the northern hemisphere, but there is no consensus if those equations are still useful for hardwoods from Brazilian forests. Here, these equations will be referred as "theoretical equations".

There are many informations about the dimensional stability of tropical Brazilian wood species $[15,16]$ and wood 
species grown in Brazil [17], and spite of that some theoretical equations were not tested regarding their accuracy, being necessary to perform these evaluations for slowly bringing new bases for the field of dimensional stability of Brazilian wood, which may lead to improvements on utilization of these wood species $[18,19]$.

This paper aims confront the theoretical equations with the physical properties of fifteen tropical Brazilian wood species, covering the five strength classes of the Brazilian standard code, and giving more informations about the accuracy of the equations used in this field, when they are applied for hardwoods from Brazil.

\section{MATERIALS AND METHODS}

\subsection{Theoretical equations}

Based on the work of Kolmann and Côte [14], four equations that are useful for determining the dimensional stability of wood samples were considered. These four equations are the following:

$$
\begin{aligned}
& \beta t=1,65 * \beta r \\
& \alpha t / \alpha r=\beta t / \beta r \\
& \alpha v / F S P=0,84 * d 0 \\
& \beta v / F S P=0,84 * d b a s
\end{aligned}
$$

In these equations, $\beta \mathrm{t}$ stands by the total swelling in the tangential direction, $\beta \mathrm{r}$ stands by the total swelling in the radial direction, $\alpha$ stands by the total shrinkage in the tangential direction, $\alpha$ stands by the total shrinkage in the radial direction, $\alpha \mathrm{v}$ stands by the total volumetric shrinkage, $\beta \mathrm{v}$ stands by the total volumetric swelling, FSP stands by the Fiber Saturation Point, $d 0$ stands by the wood density at $0 \%$ moisture content and $d b a s$ stands by the basic density of wood.

\subsection{Sampling for the experimental values determination}

For investigating the theoretical equations accuracy using robust experimental data were considered fifteen tropical Brazi-

\begin{tabular}{|c|c|c|}
\hline Strength Class & Wood Species & Number of specimens \\
\hline D20 & Pachira quinata & 12 \\
\hline D20 & Cedrela sp. & 12 \\
\hline D20 & Erisma sp. & 12 \\
\hline D30 & Cassia ferruginea & 12 \\
\hline D30 & Calophyllum sp. & 12 \\
\hline D30 & Ocotea odorifera & 12 \\
\hline D40 & Vataieropsis araroba & 12 \\
\hline D40 & Goupia glabra & 12 \\
\hline $\mathrm{D} 40$ & Vatairea fusca & 12 \\
\hline D50* & Qualea albiflora & 12 \\
\hline D50* & Gossypiospermun praecox & 12 \\
\hline D50* & Bagassa guianensis & 12 \\
\hline D60 & Dinizia excelsa & 12 \\
\hline D60 & Dipteryx sp. & 12 \\
\hline D60 & Mezilaurus itauba & 12 \\
\hline
\end{tabular}
lian wood species covering the five strength classes (three wood species for each strength class) preconized by the Brazilian Revised standard code [20] (Table 1).

Table 1: Tropical Brazilian wood species considered.

According to Almeida et al. [11], the five strength classes of the Brazilian standard code cover all range of wood densities, which is important for bests conclusions concerning this comparative study between experimental and theoretical approaches of dimensional stability of wood materials. 


\subsection{Determination of experimental values}

Experimental values were determined according to the ABNT NBR 7190/1997 "Design of Timber Structures", that prescribes procedures for wood properties characterization in its annex B "Determination of wood properties for structural design". Wood densities were determined according to the item B.6 and swelling and shrinkage values were made according to the item B.7. At least twelve repetitions should be performed for each test for wood properties characterization.

\subsection{Statistical Analysis}

We made a table summarizing the experimental values determined for the fifteen wood species, and after that, based on the four theoretical equations presented, we calculated the theoretical values of $\beta \mathrm{t}$ ', $\alpha \mathrm{t} / \alpha \mathrm{r}$ ', $\alpha \mathrm{v} / \mathrm{FSP}$ ', $\beta \mathrm{v} / \mathrm{FSP}$ ', which made possible to summarize experimental and theoretical values for all wood species considered. For better present the results, boxplots of 180 determinations for all wood species were made for experimental and theoretical groups of $\beta \mathrm{t}, \alpha \mathrm{t} / \alpha \mathrm{r}, \alpha \mathrm{v} /$ FSP, $\beta$ v/FSP values.

Finally, the nonparametric analysis of variance of Kruskal-Wallis (Kruskal-Wallis ANOVA) was used for theoretical and experimental groups comparison at 5\% significance level. According to the hypothesis of the Kruskal-Wallis ANOVA, $\mathrm{p}$-value higher than 0.05 lead us to accept the equivalence between groups, and reject it otherwise, meaning that groups are significantly different. For statistical analysis we used the software R 3.5.1 [21].

\section{RESULTS AND DISCUTIONS}

Performing the characterization of the wood samples for determining $\beta \mathrm{t}, \beta \mathrm{r}, \beta \mathrm{v}, \alpha \mathrm{t}, \alpha \mathrm{r}, \alpha \mathrm{v}, F S P, d 0$ and $d b a s$, it was possible to build the Table 2 that summarize the experimental values for fifteen tropical Brazilian wood species (180 determinations for each variable). In the tables of data summary, "CV" means coefficient of variation.

Table 2: Summary of the Experimental values.

\begin{tabular}{c|c|c|c|c|c}
\hline Variable & Average & CV (\%) & Minimum & Maximum & Count \\
\hline$\beta t$ & 7.71 & 26.71 & 4.02 & 13.97 & 180 \\
\hline$\beta r$ & 4.46 & 24.70 & 1.97 & 7.92 & 180 \\
\hline$\beta v$ & 12.44 & 23.25 & 6.84 & 20.84 & 180 \\
\hline$\alpha t$ & 8.41 & 29.15 & 4.19 & 16.24 & 180 \\
\hline$\alpha r$ & 4.68 & 25.96 & 2.01 & 8.60 & 180 \\
\hline$\alpha v$ & 14.34 & 27.00 & 7.34 & 26.33 & 180 \\
\hline$F S P$ & 21.60 & 16.70 & 15.68 & 36.04 & 180 \\
\hline$d 0$ & 0.81 & 24.70 & 0.40 & 1.24 & 180 \\
\hline$d b a s$ & 0.64 & 23.50 & 0.37 & 0.98 & 180 \\
\hline
\end{tabular}

As shown in the Table 2, the dimensional variation in the tangential directions was greater than the dimensional variation in the radial direction ( $\beta \mathrm{t}>\beta \mathrm{r}$ and $\alpha \mathrm{t}>\alpha \mathrm{r}$ ) as pointed by Almeida et al. [11] and Christoforo et al. [12]. In addition, the greatest coefficient of variation value was $29.15 \%$ for $\alpha$ and the lowest value of this parameter of variability was $16.7 \%$ for the Fiber Saturation point moisture content.

Using the equations presented, we calculated the theoretical values of $\beta t^{\prime}, \alpha t / \alpha r$ ', $\alpha v / F S P$ ', $\beta v / F S P$ ' using the $\beta r$, $\beta \mathrm{t}$, $d 0$ and dbas experimental values, which made possible to compare these theoretical values with the experimental ones, evaluating the accuracy of the theoretical equations. Table 3 presents the summary of results for $\beta \mathrm{t}, \alpha \mathrm{t} / \alpha \mathrm{r}, \alpha \mathrm{v} / \mathrm{FSP}, \beta \mathrm{v} / \mathrm{FSP}$ as experimental values, and $\beta \mathrm{t}^{\prime}, \alpha \mathrm{t} / \alpha \mathrm{r}$ ', $\alpha \mathrm{v} / \mathrm{FSP}$ ', $\beta \mathrm{v} / \mathrm{FSP}$ ' as theoretical values. Table 3 shows that experimental theoretical average values are very similar for the four parameters of comparison. On the other hand, experimental parameters presented higher coefficients of variation for all parameters. 
Table 3: Summary of experimental and theoretical parameters for comparison.

\begin{tabular}{c|c|c|c|c|c}
\hline Variable & Average & CV (\%) & Minimum & Maximum & Count \\
\hline$\beta t$ & 7.71 & 26.71 & 4.02 & 13.97 & 180 \\
\hline$\beta t^{\prime}$ & 7.36 & 24.70 & 3.25 & 13.07 & 180 \\
\hline$\alpha t / \alpha r$ & 1.84 & 27.18 & 0.98 & 4.42 & 180 \\
\hline$\beta t / \beta r$ & 1.77 & 25.60 & 0.98 & 4.12 & 180 \\
\hline$\alpha v / F S P$ & 0.69 & 34.19 & 0.24 & 1.51 & 180 \\
\hline$\alpha v / F S P^{\prime}$ & 0.68 & 24.70 & 0.34 & 1.04 & 180 \\
\hline$\beta v / F S P$ & 0.59 & 30.57 & 0.22 & 1.22 & 180 \\
\hline$\beta v / F S P^{\prime}$ & 0.54 & 23.50 & 0.31 & 0.82 & 180 \\
\hline
\end{tabular}

For better visualize the data in what concerns central tendency and dispersion measures, were built boxplots for each pair of experimental values (represented by "exp") and theoretical values (represented by "theor") (Figure 1).

For comparing experimental and theoretical groups, were performed the Kruskal-Wallis ANOVA test at 5\% significance level. Table 4 presents the p-values of the ANOVA tests performed for $\beta \mathrm{t}, \alpha \mathrm{t} / \alpha \mathrm{r}, \alpha \mathrm{v} / \mathrm{FSP}, \beta \mathrm{v} / \mathrm{FSP}$ groups.

Eq. 1: ANOVA - p.va

(a)

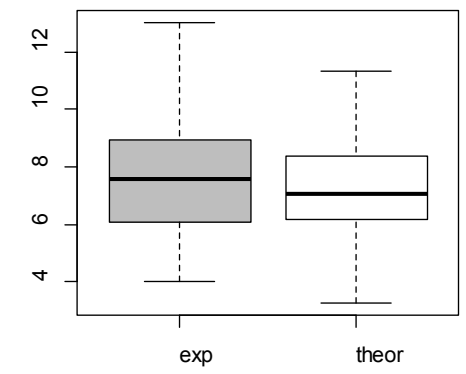

Eq. 3: ANOVA - p.va

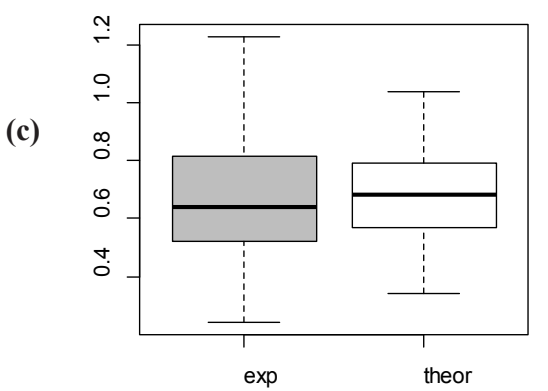

(b)

Eq. 2: ANOVA - p.va

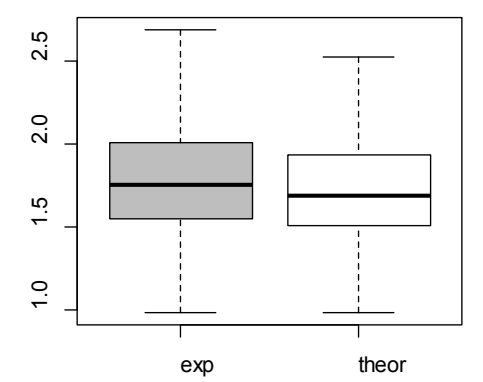

(d)

Eq. 4: ANOVA - p.va

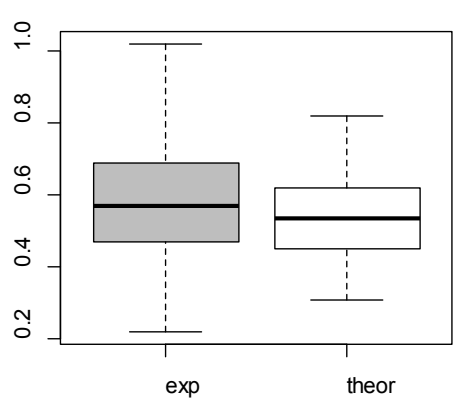

Figure 1: Boxplots of (a) $\boldsymbol{\beta}$ t experimental and theoretical values; (b) $\boldsymbol{\alpha t} / \boldsymbol{\alpha} \mathbf{r}$ experimental and theoretical values; (c) $\boldsymbol{\alpha} \mathbf{v} / \mathbf{F S P}$ experimental and theoretical values; (d) $\boldsymbol{\beta} \mathbf{v} / \mathbf{F S P}$ experimental and theoretical values.

Table 4: P-values for Kruskal-Wallis ANOVA tests performed.

\begin{tabular}{l|c|c|c}
\hline Variable & Experimental values & Theoretical values & p-value of ANOVA \\
\hline$\beta \mathrm{t}$ & 7.71 & 7.36 & 0.145 \\
\hline$\alpha \mathrm{t} / \alpha \mathrm{r}$ & 1.84 & 1.77 & 0.116 \\
\hline$\alpha \mathrm{v} / \mathrm{FSP}$ & 0.69 & 0.68 & 0.306 \\
\hline$\beta \mathrm{v} / \mathrm{FSP}$ & 0.59 & 0.54 & 0.012 \\
\hline
\end{tabular}

$\beta \mathrm{t}, \alpha \mathrm{t} / \alpha \mathrm{r}, \alpha \mathrm{v} / \mathrm{FSP}$ parameters representing the equations 1,2 and 3 provides p-values $0.145,0.116$ and 0.306 , respectively ( -value $<0.05$ ), which leads us to confirm the good accuracy of these equations. On the hand, $\beta v / F S P$ parameter, representing the equation 4 , provided p-value 0.012 ( $\mathrm{p}$-value $<0.05$ ) for experimental and theoretical values comparison, which leads us to reject the hypothesis of equivalence between these values, pointing the lack of accuracy of this equation. Therefore, the equation 4 seems do not be useful for dimensional parameters resulted from tropical Brazilian wood species. 


\section{CONCLUSIONS}

Based on the results found here we conclude that the theoretical equations proposed by Kolmann and Côte [14], can be applied for tropical Brazilian wood species, but the Equation 4. The fourth equation that involves basic density of wood for estimating the dimensional stability of wood measured by the total volumetric swelling coefficient, was the only one that did not present equivalence between theoretical and experimental values, leading us to conclude that it seems do not be so accurate as the other three equations.

\section{AKNOWLEDGEMENTS}

Authors thank CAPES for the financial support (this study was financed by the Coordenação de Aperfeiçoamento de Pessoal de Nível Superior - Brasil (CAPES) - Finance Code 001), Laboratory of Wood and Timber Structures (LaMEM) of the Engineering of Structures Department (SET) of the Engineering School of São Carlos (EESC) - University of São Paulo (USP).

\section{BIBLIOGRAPHY}

[1] ALMEIDA, D. H., ALMEIDA, T. H., CHRISTOFORO, A. L., Mechanical Properties of Wood estimated by Colorimetric Technique, Saarbrüken-Deutschland/Germany, Lambert Academic Publishing, 2018.

[2] LEWHINSOHN, T.M., PRADO, P.I. “How many species are there in Brazil?”, Conservation Biology, v.19, n.3, pp.619624, 2005.

[3] GALVÃO, A. P. M., JANKOWSKY, I. P., Secagem racional da madeira. São Paulo, Nobel, 1985.

[4] KOKUTSE, A., BRANCHERIAU, L., CHAIX, G. "Rapid prediction of shrinkage and fiber saturation point on teak (Tectona grandis) wood based on near-infrared spectroscopy”, Annals of Forest Science, v.67, n.4, pp.403-403. 2010.

[5] STEEGE, H., VAESSEN, R.W., LÓPEZ, D.C., et al. "The discovery of the Amazonian tree flora with an update checklist of all known tree taxa”, Scientific Reports, v.6, n.29549, pp.1-15, 2013.

[6] CALIL JUNIOR, C., LAHR, F. A. R., DIAS, A. A., Dimensionamento de elementos estruturais de madeira, Barueri, Manole, 2003.

[7] PASSARINI, L., HERNÁNDEZ, R. E. "Effect of the desorption rate on the dimensional changes of Eucalyptus saligna wood", Wood Science and Technology, v.50, n.5, pp.941-951. 2016.

[8] ALMEIDA, T.H., ALMEIDA, D.H., ARAÚJO, V.A., et al."Density as estimator of dimensional stability quantities of Brazilian tropical woods", BioResources, v.12, n.3, pp.6579-6590. 2017.

[9] YE, X., WANG, S., RUAN, R. "Water Mobility and Mold Susceptibility of Engineered Wood Products”. Transactions of The Asabe, v.49, n.4, pp.1159-1165. 2006.

[10] ASSOCIAÇÃO BRASILEIRA DE NORMAS TÉCNICAS. ABNT NBR 7190: Projeto de estruturas de madeira. Rio de Janeiro: ABNT, 1997.

[11] ALMEIDA, T.H., ALMEIDA, D.H., CHRISTOFORO, A.L., et al. "Density as estimator of strength in compression parallel to the grain in wood”, International Journal of Materials Engineering, v.6, pp.67-71, 2016.

[12] CHRISTOFORO, A. L.; AFTIMUS, B. H. C.; PANZERA, T. H., et al."Physico-mechanical characterization of the Anadenanthera colubrina wood specie", Journal of the Brazilian Association of Agricultural, v.37 n.2, pp.376-384. 2017.

[13] SALES, A., LAHR, F. A. R. "Strength and Stiffness Classes of Brazilian Timbers: The New Brazilian Code for Design of Timber Structures", International Journal of Civil \& Environmental Engineering, v.14, pp. 1-5.

[14] KOLlMANN, F., CÔTÉ, W. A., Principles of wood science and technology. Germany, Springer Verlag, 1968.

[15] JANKOWSKA, A., KOZAKIEWICZ, P. "Determination of Fiber Saturation Point of Selected Tropical Wood Species Using Different Methods". Drewno. Prace Naukowe. Doniesienia. Komunikaty, n.197, p.89-97. 2016.

[16] PASSARINI, L., MALVEAU, C., HERNÁNDEZ, R. "Water state study of wood structure of four hardwoods below fiber saturation point with nuclear magnetic resonance", Wood and fiber science: journal of the Society of Wood Science and Technology, v.46, pp.480-488. 2014.

[17] SOARES, A. K., LOURENÇON, T. V., DELUCIS, R. A., et al."Composição química e estabilidade dimensional da madeira de três eucaliptos". Matéria (rio de Janeiro), v.23, n 4, pp.1-7. 2018. 
[18] MURATA, K., WATANABE, Y., NAKANO, T. "Effect of Thermal Treatment on Fracture Properties and Adsorption Properties of Spruce Wood”, Materials, v.6, n.9, pp.4186-4197, 2013.

[19] ZAUER M., KRETZSCHMAR J., PFRIEM, A., et al."Analysis of the pore-size distribution and fiber saturation point of native and thermally modified wood using differential scanning calorimetry". Wood Science and Technology, v.48, n.1, pp.177-193. 2013.

[20] ASSOCIAÇÃO BRASILEIRA DE NORMAS TÉCNICAS. PN02: 126.10-001-1 (ABNT NBR 7190: Projeto de estruturas de madeira). Rio de Janeiro: ABNT, 2013.

[21] R Core Team. "R: A language and environment for statistical computing", R Foundation for Statistical Computing, Vienna, Austria. URL https://www.R-project.org/, 2018.

\section{ORCID:}

Tiago Hendrigo de Almeida Fabiane Salles Ferro

Diego Henrique de Almeida André Luis Christoforo

Francisco Antonio Rocco Lahr
https://orcid.org/0000-0001-7204-350X https://orcid.org/0000-0003-0071-9472 https://orcid.org/0000-0002-6220-4004 https://orcid.org/0000-0002-4066-080X https://orcid.org/0000-0002-3510-8498 